\title{
Aspilota ajara sp. n. (Hymenoptera, Braconidae, Alysiinae), the first species of the genus Aspilota Foerster from caves
}

\author{
Francisco Javier Peris-Felipo', Rafael García-Becerra², Sergey A. Belokobylskij ${ }^{3}$ \\ I Bleichestrasse 15, CH-4058 Basel (Switzerland) 2 C/ El Pilar n 8, $3^{\circ}$ pta.1. 38700-S/C de La Palma, \\ Tenerife, Canary Islands, Spain 3 Zoological Institute, Russian Academy of Sciences, St Petersburg 199034, \\ Russia; Museum and Institute of Zoology, Polish Academy of Sciences, Wilcza 64, Warszawa 00-679, Poland \\ Corresponding author: Francisco Javier Peris-Felipo (peris.felipo@gmail.com) \\ Academic editor: G. Broad | Received 1 August 2016 | Accepted 13 September 2016 | Published 28 October 2016 \\ http://zoobank.org/AB0D6062-E2B6-4902-98D7-5576D77F3FFA \\ Citation: Peris-Felipo FJ, García-Becerra R, Belokobylskij SA (2016) Aspilota ajara sp. n. (Hymenoptera: Braconidae: \\ Alysiinae), the first species of the genus Aspilota Foerster from caves. Journal of Hymenoptera Research 52: $153-162$. \\ doi: $10.3897 /$ jhr. 52.10067
}

\begin{abstract}
Aspilota ajara sp. n., a new species of the $A$. miraculosa (fasciatae) species group with very short upper tooth, was collected in a cave on La Palma, Canary Islands, Spain. This is the first Aspilota species known to occur in caves as well as the first record of Aspilota for the Canary Islands. The new species is described, illustrated and compared with related taxa.
\end{abstract}

\section{Keywords}

Braconidae, Alysiinae, Aspilota, parasitoid, caves, description, La Palma

\section{Introduction}

The Alysiinae is an extremely diverse subfamily of parasitoids of the family Braconidae (Dolphin and Quicke 2001) with about 2,300 already described species (Yu et al. 2012), which are divided in to two large and morphologically diverse tribes, Alysiini and Dacnusini (Shenefelt 1974). Members of the tribe Alysiini are parasitoids 
of Diptera-Cyclorrhapha, usually inhabiting humid substrates (Wharton 1984; Yu et al. 2012). Dacnusini are almost exclusively specialized on leaf and stem miner flies, mainly from the families Agromyzidae, Chloropidae and Ephydridae (Belokobylskij 2005; Peris-Felipo et al. 2014).

The genus Aspilota Foerster, 1863 is one of the largest taxa of the Aspilota genus group (Alysiini) with approximately 250 species described almost from all zoogeographical regions. Species of Aspilota are well defined by the presence of the large paraclypeal fovea connecting with the inner margin of the eye and the presence of fore wing vein cuqu1 (2-SR) (van Achterberg 1988; Peris-Felipo and Belokobylskij 2016a).

A new species, Aspilota ajara sp. n., from the $A$. miraculosa (fasciatae) species group (characterized by the small size of the upper tooth of the mandible) is described and illustrated in this paper. This is the first record of an Aspilota species collected in caves and also the first record of the genus Aspilota for the Canary Islands.

\section{Materials and methods}

\section{Area of study}

La Palma Island (Canaries Islands) has a subtropical climate, with annual average temperature of $24.2^{\circ} \mathrm{C}$ (winters of $20-22$ and summers of $25-28^{\circ} \mathrm{C}$ ) and a low annual average rainfall of $135 \mathrm{~mm}$ (AEMET 2016). The "Llano de Los Caños" cave is located in Villa de Mazo (La Palma, Canary Islands, Spain), close to the La Sabina and Tirimaga (Fig. 1). The cave is almost a linear tube with a length of $1,200 \mathrm{~m}$ and with several short branches. It has a single entrance at the mountain of La Horqueta (1365 m; UTM 28RBS262646). Recently, a new section called "Galerias de los Zapadores" was opened (Fernández et al. 2015). However, our area of study belongs to the classic section ("Tramo clásico").

\section{Methodology}

Samples were carried out at four sampling points (E) located in the main cave in complete darkness during 1995 (Fig. 2). At each point, four pitfall traps were placed at the beginning of each annual season and were checked two weeks later. Automobile antifreeze liquid was used as preservative and pieces of cheese were used as bait (García and González 1998).

The first sampling point (E1) was located at $20 \mathrm{~m}$ from the entrance in earthysandy soil. The second (E2) was placed at 70 meters from the entrance and has an earthy substrate and also a crack of $30 \mathrm{~cm}$ which divides the cave into two. The third point (E3) was situated at 90 meters from the entrance, in earthy substrate. The last 


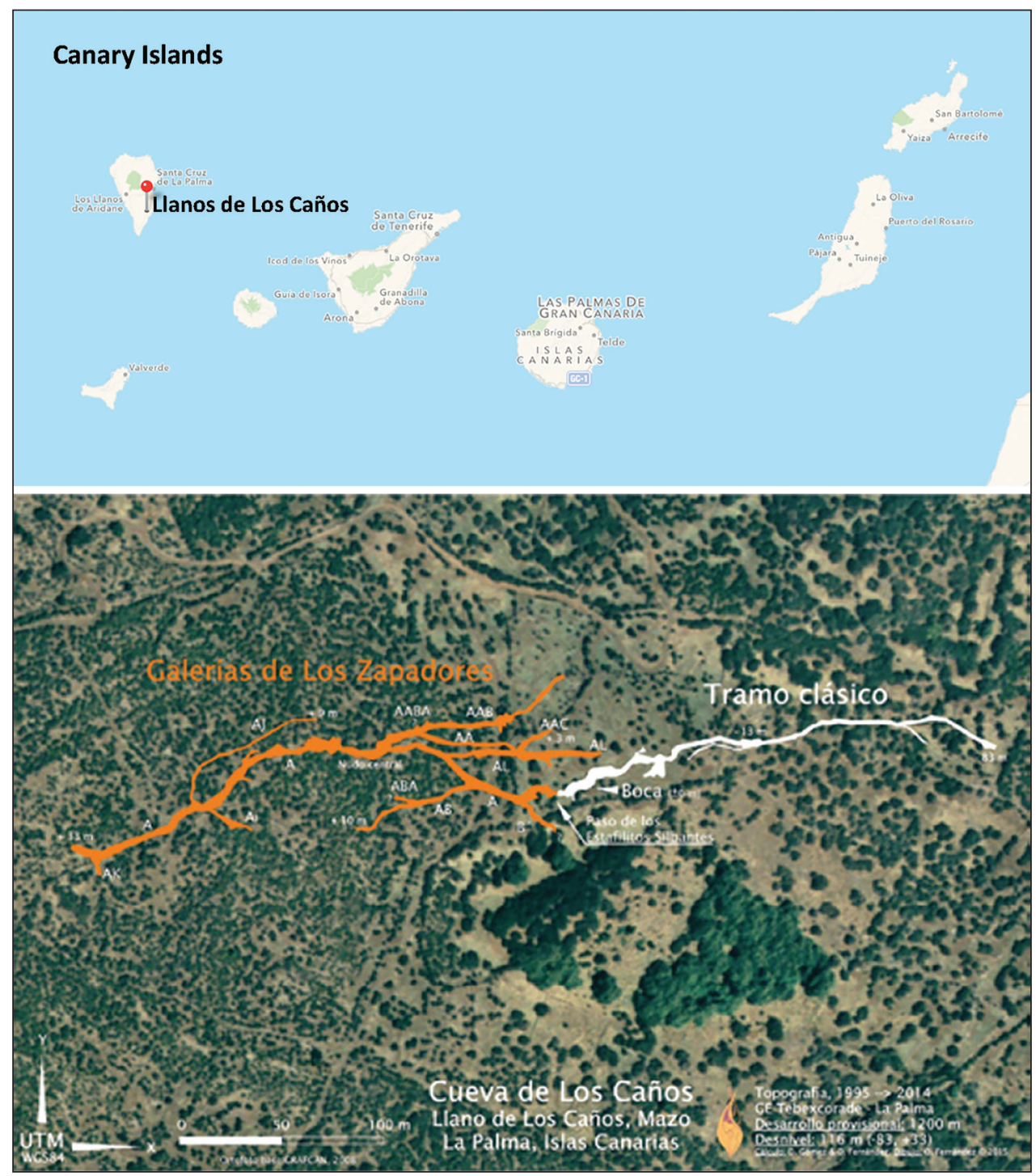

Figure I. Location of studied cave in Canary Islands (Spain) and in La Horqueta Mountain.

sampling point (E4) was located at $190 \mathrm{~m}$. from the entrance in a substrate built up from the remains of demolition (García and González 1998). Climatic conditions and distance from the cave entrance are given in Table 1.

For terminology of morphological features, sculpture and measurements, see Peris-Felipo et al. (2014); for wing venation nomenclature, see Peris-Felipo et al. (2014) and, in parentheses, van Achterberg (1993). The keys by Fischer $(1976,1978)$, Belokobylskij and Tobias (2007) and Papp (2008) were used for the identification of 


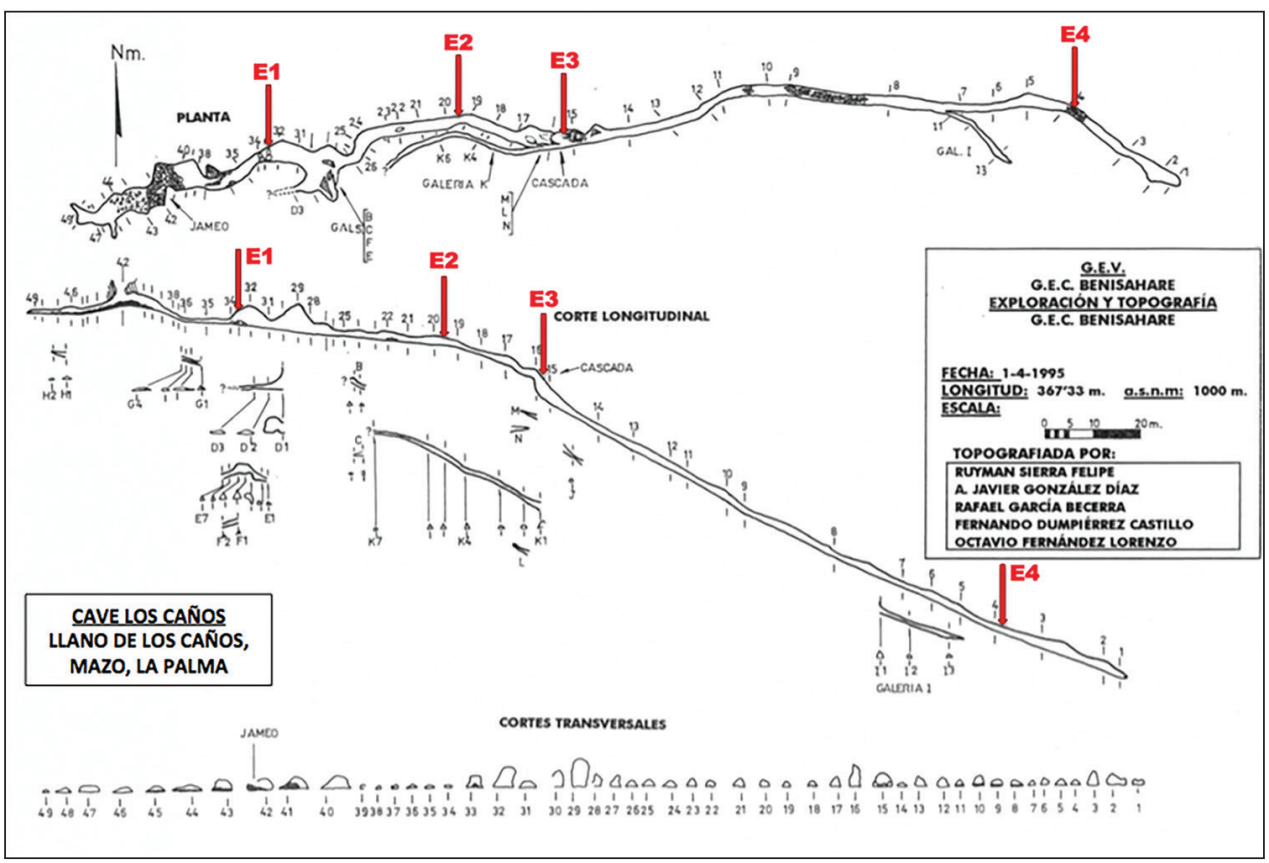

Figure 2. Map of the "Llano de Los Cańos" cave with sampling points E1-E4 in red.

Table I. Climatic conditions and distance from the cave entrance for the sampling points.

\begin{tabular}{c|c|c|c}
\hline Sampling points (E) & $\begin{array}{c}\text { Distance from cave } \\
\text { entrance (m) }\end{array}$ & Temperature $\left({ }^{\circ} \mathbf{C}\right)$ & Relative Humidity (\%) \\
\hline E1 & 20 & - & - \\
\hline E2 & 70 & 14.5 & 92.3 \\
\hline E3 & 90 & 13.9 & - \\
\hline E4 & 190 & 16.3 & 94.3 \\
\hline
\end{tabular}

Aspilota species. The material was imaged using Digital Microscope Keyence ${ }^{\varpi}$ VHX2000 and Adobe Photoshop ${ }^{\oplus}$ imaging system.

Type specimens are deposited in the following collections: holotype in the Natural History Museum of Tenerife (Tenerife, Canary Islands, Spain; MNHT); paratypes in the Entomological Collection at University of Valencia (Valencia, Spain; ENV), Museo Nacional de Ciencias Naturales (Madrid, Spain; MNCN), Entomological Collection at University of La Laguna (La Laguna, Canary Islands, Spain; CULL), Natural History Museum of Tenerife (Tenerife, Canary Islands, Spain; MNHT), Zoological Institute RAS (St Petersburg, Russia; ZISP), and in the private collection of Rafael García Becerra (La Palma, Canary Islands, Spain; RGB). 


\title{
Taxonomic part
}

\author{
Order Hymenoptera \\ Family Braconidae \\ Subfamily Alysiinae \\ Genus Aspilota Foerster, 1863
}

\section{Aspilota ajara Peris-Felipo, sp. n.}

http://zoobank.org/109B16EB-AFBE-4184-B34C-D9AD36067891

Figs 3, 4

Type material. Holotype: female, Spain: Canary Islands, La Palma, Villa de Mazo, Llano de los Caños cave, 15.iii.1995 (R. García-Becerra leg.) (MNHT).

Paratypes. Spain, 27 females, same data as holotype, but iii, vi, ix \& xii.1995 (CULL, ENV, MNCN, MNHT, RGB, ZISP).

Description. Female (holotype). Head. In dorsal view twice as wide as its median length, 1.3 times as wide as mesoscutum, with rounded temples behind eyes. Head at level of temple (dorsal view) as wide as at level of eyes. Eye in lateral view 1.6 times as high as wide and 0.9 times as wide as temple medially; in dorsal view about as wide as temple. POL 1.5 times OD; OOL 4.7 times OD. Face 1.7 times as wide as high; inner margins of eyes subparallel. Clypeus slightly curved ventrally, 2.3 times as wide as high. Mandible weakly widened towards apex, 1.4 times as long as maximum width. Upper tooth of mandible distinctly shorter than middle and lower teeth, develop as rounded lobe; middle tooth long, narrow and pointed; lower tooth longer than upper tooth, wide, rounded apically. Antenna thick, 19-segmented, 1.1 times as long as body. Scape 2.1 times as long as pedicel. First flagellar segment 3.2 times as long as its apical width, 1.1 times as long as second segment; second segment 3.0 times as long as its maximum width, third to ninth segments 2.8 times, 10th to 14th 2.6 times, 15th segment 2.2 times, 16th segment 2.5 times, and 17th (apical) 2.75 times as long as their maximum width accordingly.

Mesosoma in lateral view about 1.2 times as long as high. Mesoscutum 1.1 times as long as maximum width. Notauli mainly absent on horizontal surface of mesoscutum. Mesoscutal pit absent. Prescutellar depression smooth, only with median carinae. Precoxal suture present, not reaching anterior and posterior margins of mesopleuron. Posterior mesopleural furrow crenulate in upper part and smooth below. Propodeum sculptured, with pentagonal areola. Propodeal spiracle small.

Legs. Hind femur 4.7 times as long as its maximum width. Hind tibia slightly widened towards apex, 12.0 times as long as its maximum subapical width, as long as hind tarsus. First segment of hind tarsus 2.6 times as long as second segment.

Wings. Length of fore wing 2.8 times its maximum width. Radial (marginal) cell ending at apex of wing, 1.5 times as long as its maximum width. Vein cuqu1 (2-SR) present and sclerotized. Vein r2 (3-SR) 2.7 times as long as vein cuqu1 (2-SR); vein r3 (SR1) 2.1 times as long as vein r2 (3-SR). Nervulus (cu-a) strongly postfurcal. Brachial 

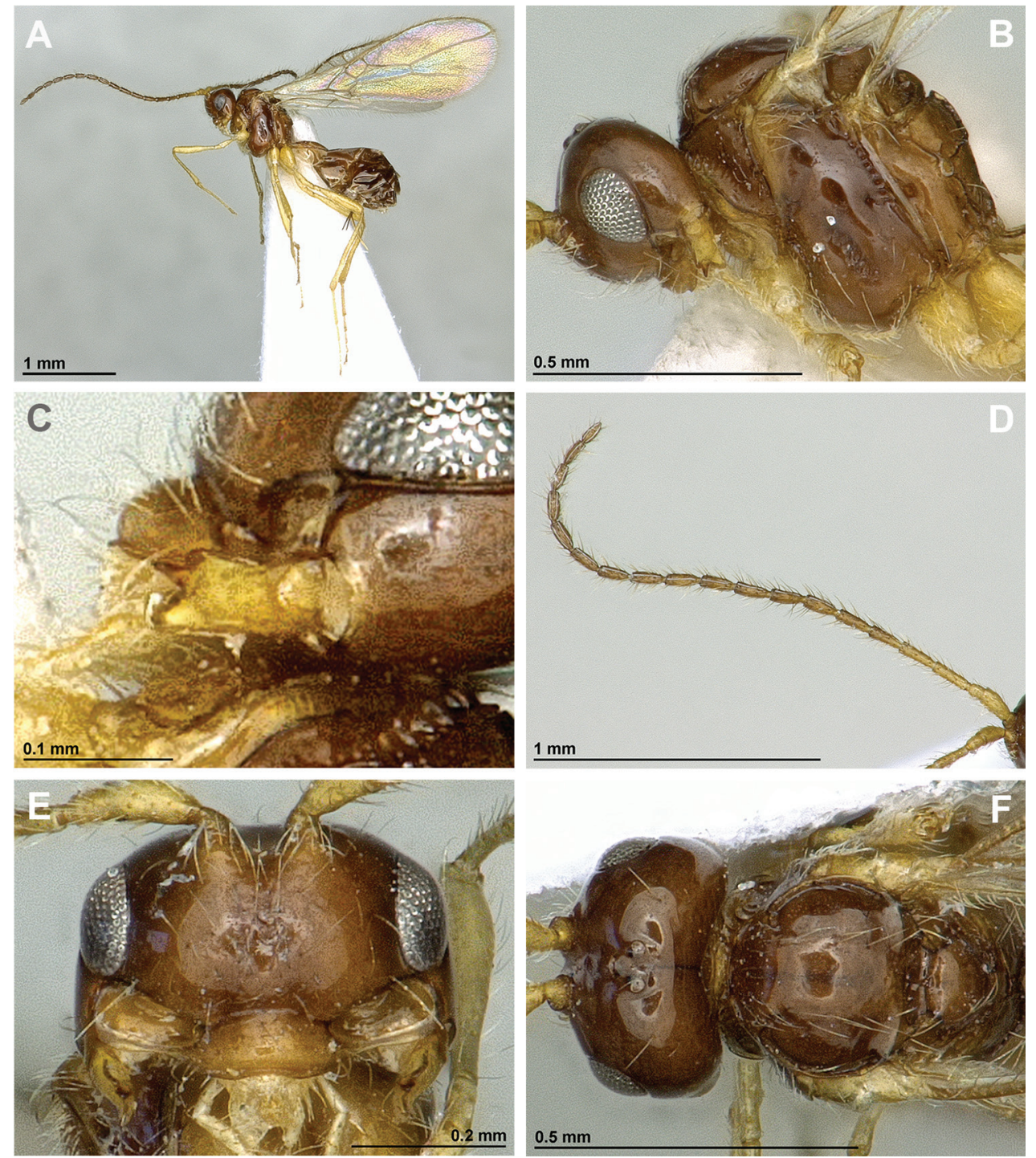

Figure 3. Aspilota ajara sp. n. (female). A Habitus, lateral view B Head and mesosoma, lateral view C Mandible D Antenna E Face, front view $\mathbf{F}$ Head and mesonotum, dorsal view.

(subdiscal) cell closed distally, 2.3 times as long as its maximum width. Hind wing 6.3 times as long as its maximum width.

Metasoma. Distinctly compressed. First tergite smooth medially, weakly rugulose laterally, widened towards apex, 2.3 times as long as its apical width. Ovipositor 1.3 times as long as first tergite, distinctly shorter than metasoma, 0.8 times as long as hind femur.

Colour. Body reddish brown, metasoma paler. Antenna mainly pale brown, four basal segments yellow. Mandible and legs yellow. Wings hyaline.

Length. Body $-2.0 \mathrm{~mm}$; fore wing $-2.4 \mathrm{~mm}$; hind wing $-1.7 \mathrm{~mm}$. 

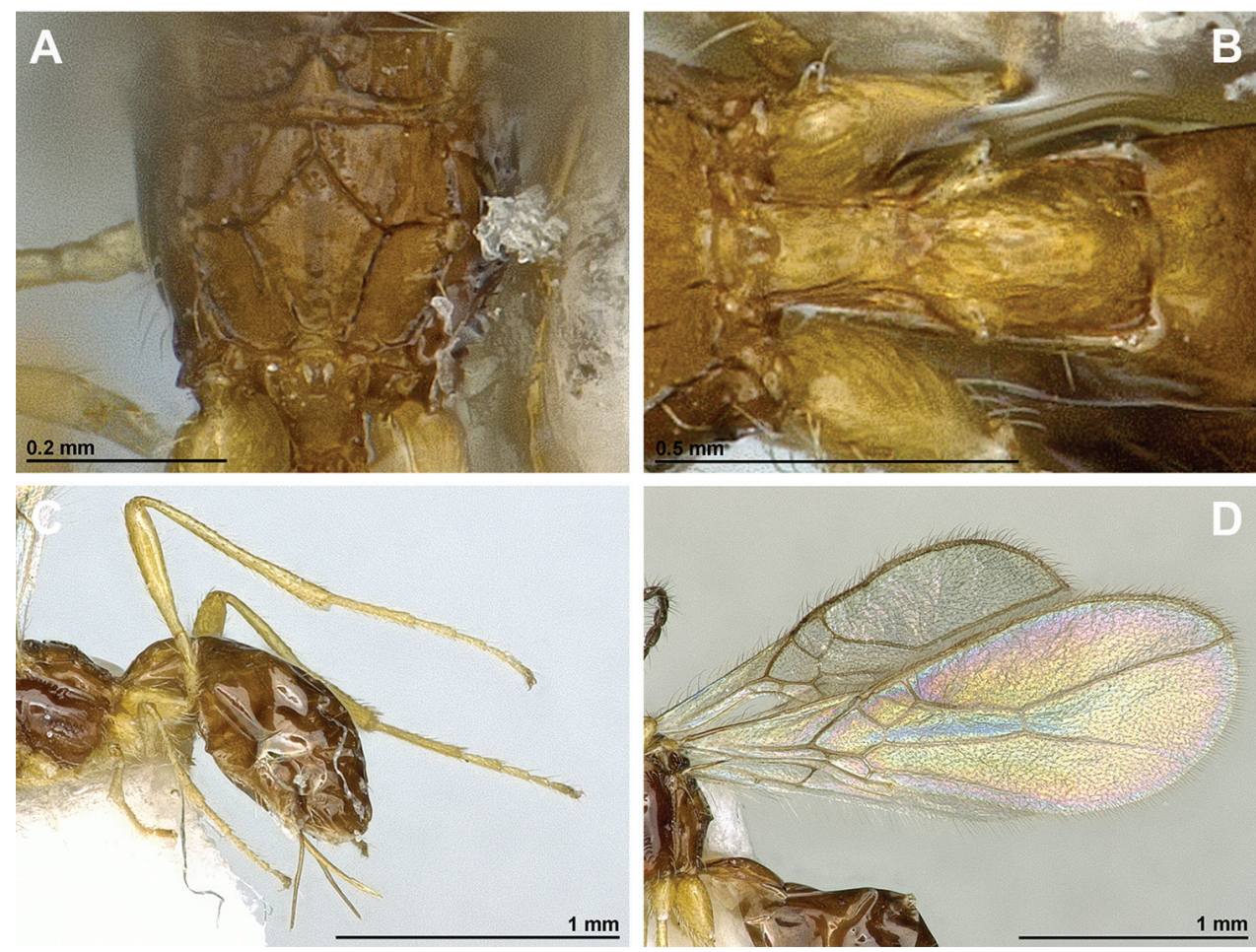

Figure 4. Aspilota ajara sp. n. (female). A Propodeum, dorsal view B First metasomal tergite C Metasoma, hind leg and ovipositor, lateral view $\mathbf{D}$ Fore and hind wings.

Variation. Body length 1.9-2.5 mm; fore wing length 2.3-2.7 mm; hind wing length 1.6-1.9 mm. Otherwise similar to holotype.

Etymology. The name is derived from Canary dialect "ájara" meaning "be fortunate", referring to the difficulty in finding this genus in the caves.

Comparative diagnosis. This new species is similar to A. insolita (Tobias, 1962) (U.K., Ireland, Denmark, Spain, Hungary, former Czechoslovakia, European part of Russia, Iran: Peris-Felipo et al. 2016) as they share the sculptured, pentagonal areola on the propodeum, eye in lateral view 0.9-1.0 times as wide as the temple medially, mandible 1.4 times as long as its maximum width, and sixth flagellar segment 2.6-2.8 times as long as its maximum width.

Aspilota ajara sp. n. differs from $A$. insolita in having the head in dorsal view twice as wide as its median length (1.8 times in $A$. insolita), head in dorsal view 1.3 times as wide as mesoscutum (1.6 times in $A$. insolita), face 1.7 times as wide as high (1.9 times in $A$. insolita), clypeus 2.3 times as wide as high (1.6 times in $A$. insolita), head at level of eyes in dorsal view about as wide as head at level of temple (1.2 times in $A$. insolita), the first flagellar segment 3.2 times as long as its maximum width (4.7-5.3 times in $A$. insolita), and hind femur 4.7 times as long as its maximum width (4.0-4.1 times in $A$. insolita). 
In Belokobylskij's (Belokobylskij and Tobias 2007) key, A. ajara sp. n. runs to the Eastern Palaearctic A. tshirikovi Belokobylskij, 2007 (Russian Far East and Japan), but differs in having the lower mandibular tooth long (short in $A$. tshirikovi), middle and apical antennal segments slender and long (thick and short in A. tshirikovi), face 1.7 times as wide as high (1.2-1.4 times in A. tshirikovi), and paraclypeal fovea wide (rather narrow in $A$. tshirikovi).

General distribution. Canary Islands (Spain).

Remarks. Specimens were found in all traps but mainly in E2 and E3 sampling points. One specimen was captured in each of March and June, five in September and 21 in December. Unfortunately, it is not possible to report precise collection data for sampling points and dates because the notes with this complete information were destroyed in a flood. The following Diptera were sampled in the same traps: Calliphora vicina Robineau-Desvoidy, 1830 (Calliphoridae), Megaselia sp. (Phoridae) and Aptilotus martini Wheeler \& Marshall, 1989 (Sphaeroceridae) (García and González 1998). However, it is impossible to establish any biological relationships between them.

\section{Discussion}

Subterranean ecosystems have always interested people and there has been great scientific interest in cave fauna. Proof of this is in the significant number of animal species found and described from these peculiar localities. However, only nine species of Braconidae, belonging to the genera Aleiodes Wesmael, 1838 (Rogadinae), Apanteles Foerster, 1863 (Microgastrinae), Aulosaphes Muesebeck, 1935 (Lysiterminae), Dinotrema Foerster, 1863 (Alysiinae), Ontsira Cameron, 1900 and Spathius Nees, 1819 (Doryctinae) have been cataloged from subterranean environments (Peris-Felipo and Belokobylskij 2016b). The description of Aspilota ajara sp. n. provides the first record of Aspilota for the cave biota.

It is possible that most braconids collected in subterranean environments (caves, galleries or chasms) found their way there accidentally, searching for host refuges (Peris-Felipo and Belokobylskij 2016b). However, hosts of Alysiini (Alysiinae), which include also sarcophagous and necrophagous Diptera, as well as parasitoids (Calliphoridae, Muscidae, Sarcophagidae, and Phoridae), are common and distinct elements of cave fauna and we suggest that they have acquired stable parasitoid faunas in these peculiar subterranean conditions. Interestingly, no braconid parasitoids known from subterranean environments have any outstanding morphological characters (including colour) associated with subterranean life. Either these insects have relatively recently penetrated these environments, with insufficient time for major morphological adaptations, or they have regular contact with areas outside caves. To conclude, further studies on caves are recommended in order to improve our knowledge of these parasitoids from caves, which remain largely unknown. 


\section{Acknowledgement}

We wish to thank Gloria Ortega Muñoz, a researcher at the Natural History Museum of Tenerife (Canary Islands, Spain), for help with collecting material for this study and Dr Gavin Broad for professional correction of our manuscript and valuable suggestions. We are also thankful to Isabelle Zürcher-Pfander and Matthias Borer (Naturhistorisches Museum Basel, Switzerland) for their kindness and help during our work with the photosystem in the Museum of Basel. This work was partly supported for SAB by the Russian Foundation for Basic Research (project No. 16-04-00197) and the Russian State Research Project No. 01201351189.

\section{References}

Achterberg C van (1988) The genera of the Aspilota-group and some descriptions of fungicolous Alysiini from Netherlands (Hymenoptera: Braconidae: Alysiinae). Zoologische Verhandelingen Leiden 247: 1-88.

Achterberg C van (1993) Illustrated key to the subfamilies of the Braconidae (Hymenoptera: Ichneumonoidea). Zoologische Verhandelingen Leiden 283: 1-189.

AEMET (2016) Agencia Estatal de Metereología. http://www.aemet.es

Belokobylskij SA (2005) Eastern Palaearctic species of parasitic wasps of the genus Aspilota Förster (Hymenoptera, Braconidae, Alysiinae). Species with developed mesoscutal pit. Entomological Review 85(6): 675-701.

Belokobylskij SA, Tobias VI (2007) Fam. Braconidae. Subfam. Alysiinae. Group of genera closed to Aspilota. In: Lelej AS (Ed.) Key to insects of the Russian Far East. Neuropteroidea, Mecoptera, Hymenoptera. Dal'nauka (Vladivostok) 4(5): 9-133. [In Russian]

Dolphin K, Quicke DLJ (2001) Estimating the global species richness of an incompletely described taxon: an example using parasitoid wasps (Hymenoptera: Braconidae). Biological Journal of the Linnean Society 73: 279-286. doi: 10.1111/j.1095-8312.2001.tb01363.x

Fernández O, Gómez D, Naranjo M, Jurado V (2015) Nuevas galerías en la Cueva de Los Caños (Mazo, La Palma, Islas Canarias). Notas sobre espeleometría, biocenosis y microbiología. Convenció Internacional d'Espeleologia Barcelona: 111-120.

Fischer M (1976) Erste Nachweise von Aspilota-Wespen in Burgenland (Hymenoptera, Braconidae, Alysiinae). Annalen des Naturhistorisches Museum Wien 80: 343-410.

Fischer M (1978) Neue Alysiinen von Neu Guinea, Neu Britannien und den Philippinen (Hymenoptera, Braconidae, Alysiinae). Annalen des Naturhistorisches Museum Wien 81: 479-497.

García R, González AJ (1997) Estudio faunístico de la cueva del Llano de Los Caños (La Palma, Islas Canarias). Vieraea 26: 113-119.

Papp J (2008) Seven new species of Aspilota Foerster from the Palaearctic region (Hymenoptera: Braconidae, Alysiinae). Annales Historico-Naturales Musei Nationalis Hungarici 100: $245-269$. 
Peris-Felipo FJ, Belokobylskij SA (2016a) First record of the genus Dinotrema Foerster, 1863 (Hymenoptera, Braconidae, Alysiinae) from the Neotropical region with description of four new species and a key to the New World taxa. European Journal of Taxonomy 179: 1-23. doi: 10.5852/ejt.2016.179

Peris-Felipo FJ, Belokobylskij SA (2016b) Avispas parasitoides de la familia Braconidae en ambientes subterráneos (Braconidae parasitoid wasps (Hymenoptera) from subterranean environments). Acta Congreso de Espeleologia "EspeleoMeeting Ciudad de Villacarrillo", Villacarrillo, Jaen, 45-48.

Peris-Felipo FJ, Belokobylskij SA, Jiménez-Peydró R (2014) Revision of the Western Palaearctic species of the genus Dinotrema Foerster, 1862 (Hymenoptera, Braconidae, Alysiinae). Zootaxa 3885(1): 1-483. doi: 10.11646/zootaxa.3885.1.1

Peris-Felipo FJ, Ameri A, Rakhshani E, Belokobylskij SA (2016) The genus Aspilota Foerster (Hymenoptera: Braconidae: Alysiinae) in Western Asia. Journal of Insect Biodiversity and Systematics 2(2): 259-283.

Shenefelt RD (1974) Pars 11. Braconidae 7. Alysiinae. In: Van der Vecht J, Shenefelt RD (Eds) Hymenopterorum Catalogus (nova edition). Dr. W. Junk. B. V. The Hague, Junk, 937-1113.

Wharton RA (1984) Biology of Alysiini (Hymenoptera: Alysiinae), parasitoids of cyclorrhaphous Diptera. Technical Monograph 11: 1-39.

Yu DS, van Achterberg C, Horstman K (2012) Taxapad 2012, Ichneumonoidea 2011. Database on flash-drive. Ottawa, Ontario, Canada. 